University of Nebraska - Lincoln

DigitalCommons@University of Nebraska - Lincoln

Papers in the Earth and Atmospheric Sciences

Earth and Atmospheric Sciences, Department

July 2001

\title{
Late Quaternary Climate and Hydrology of Tropical South America Inferred from an Isotopic and Chemical Model of Lake Titicaca, Bolivia and Peru
}

\author{
Scott L. Cross \\ Duke University, cross@navo.navy.mil \\ Paul A. Baker \\ Duke University, pbaker@duke.edu \\ Geoffrey O. Seltzer \\ Syracuse University \\ Sherilyn C. Fritz \\ University of Nebraska-Lincoln, sfritz2@unl.edu \\ Robert B. Dunbar \\ Stanford University
}

Follow this and additional works at: https://digitalcommons.unl.edu/geosciencefacpub

Part of the Earth Sciences Commons

Cross, Scott L.; Baker, Paul A.; Seltzer, Geoffrey O.; Fritz, Sherilyn C.; and Dunbar, Robert B., "Late Quaternary Climate and Hydrology of Tropical South America Inferred from an Isotopic and Chemical Model of Lake Titicaca, Bolivia and Peru" (2001). Papers in the Earth and Atmospheric Sciences. 38. https://digitalcommons.unl.edu/geosciencefacpub/38

This Article is brought to you for free and open access by the Earth and Atmospheric Sciences, Department of at DigitalCommons@University of Nebraska - Lincoln. It has been accepted for inclusion in Papers in the Earth and Atmospheric Sciences by an authorized administrator of DigitalCommons@University of Nebraska - Lincoln. 
Published in Quaternary Research 56:1 (July 2001), pp. 1-9; doi 10.1006/qres.2001.2244

Copyright (C) 2001 University of Washington. Published by Academic Press/Elsevier. Used by permission.

http://www.sciencedirect.com/science/journal/00335894

Submitted November 5, 1999; published online March 11, 2002.

\title{
Late Quaternary Climate and Hydrology of Tropical South America Inferred from an Isotopic and Chemical Model of Lake Titicaca, Bolivia and Peru
}

\author{
Scott L. Cross ${ }^{a, *}$, Paul A. Baker ${ }^{a}$, Geoffrey O. Seltzer ${ }^{b}$, Sherilyn C. Fritz ${ }^{c}$, and Robert B. Dunbar ${ }^{d}$ \\ ${ }^{a}$ Division of Earth and Ocean Sciences, Duke University, Durham, North Carolina, 27708 \\ ${ }^{b}$ Department of Geology, Syracuse University, Syracuse, New York, 13244 \\ ${ }^{\mathrm{c}}$ Department of Geosciences, University of Nebraska-Lincoln, Lincoln, Nebraska, 68588 \\ ${ }^{\mathrm{d}}$ Department of Geological and Environmental Sciences, Stanford University, Stanford, California, 94305 \\ * Present Address: Naval Oceanographic Office, Ocean Modeling and Prediction Division, \\ Code N33, Stennis Space Center, MS 39522; email: cross@navo.navy.mil.
}

\begin{abstract}
A simple mass balance model provides insight into the hydrologic, isotopic, and chemical responses of Lake Titicaca to past climatic changes. Latest Pleistocene climate of the Altiplano is assumed to have been $20 \%$ wetter and $5^{\circ} \mathrm{C}$ colder than today, based on previous modeling. Our simulation of lacustrine change since 15,000 cal yr B.P. is forced by these modeled climate changes. The latest Pleistocene Lake Titicaca was deep, fresh, and overflowing. The latest Pleistocene riverine discharge from the lake was about 8 times greater than the modern average, sufficient to allow the expansion of the great paleolake Tauca on the central Altiplano. The lake $\delta^{18} \mathrm{O}$ value averaged about $-13 \%$ SMOW (the modern value is about $-4.2 \%$ ). The early Holocene decrease in precipitation caused Lake Titicaca to fall below its outlet and contributed to a rapid desiccation of paleolake Tauca. Continued evaporation caused the 100-m drop in lake level, but only a slight (1-2\%) increase (relative to modern) in $\delta^{18} \mathrm{O}$ of early Holocene lake waters. This Holocene lowstand level of nearly 100 $\mathrm{m}$ was most likely produced by a precipitation decrease, relative to modern, of about $40 \%$. The lake was saline as recently as 2,000 cal yr B.P. The timing of these hydrologic changes is in general agreement with calculated changes of insolation forcing of the South American summer monsoon.
\end{abstract}

Keywords: Lake Titicaca, Altiplano, lake level, paleohydrology, isotope chemistry
Introduction

Lake Titicaca is a large, high-altitude, tropical lake located on the Altiplano of the Andes in Bolivia and Peru. The lake has been the target of paleoclimatic investigation for the past two decades. However, most of these studies were based on cores from a shallow (40 m maximum depth) basin known as Lago Huiñaimarca (Wirrmann and Oliveira Almeida, 1987; Wirrmann et al., 1988, 1992; Ybert; 1992; Mourguiart et al., 1995; Wirrmann and Mourguiart, 1995; Abbott et al., 1997; Binford et al., 1997). These studies indicated that Lago Huiñaimarca underwent a period of desiccation that began in the late Pleistocene or early Holocene and ended at about 3,800 cal yr B.P. A single core from the much-deeper main basin (known as Lago Grande) suggested the maximum lowstand reached about $55 \mathrm{~m}$ below present lake level (Mourguiart et al., 1995; Wirrmann and Mourguiart, 1995). Our recent work based on a suite of cores from Lago Grande (Cross et al., 2000) and on seismicreflection evidence (Seltzer et al., 1998) indicates an early and middle Holocene lake-level lowering of 85-100 m from a large decrease in effective moisture on the Altiplano.

The Altiplano also underwent periods of increased effective moisture in the late Pleistocene, each associated with episodes of lake expansion to the south of Lake Titicaca (e.g., Servant and Fontes, 1978; Sylvestre et al., 1999; Baker et al., 1999). Ancient shorelines, marked by carbonate bioherm deposits on the central Altiplano, show that the most recent paleolake, known as Lake Tauca, covered about $60,000 \mathrm{~km}^{2}$ and obtained 
depths greater than $100 \mathrm{~m}$ (Bills et al., 1994; Blodgett et al., 1997; Sylvestre et al., 1999). The Tauca lacustrine phase (including the subsequent, smaller Coipasa phase) lasted from about $25,000 \mathrm{cal}$ yr B.P. to about $12,000 \mathrm{cal}$ yr B.P. (Servant et al., 1995; Sylvestre et al., 1999; Baker et al., 1999). Prior to the Tauca phase, wet and dry conditions alternated on the Altiplano for at least a few hundred thousand years (Servant and Fontes, 1978; Seltzer et al., 1999; Baker et al., 1999).

The water balance of the Altiplano has thus changed substantially on time scales of thousands of years, and these changes likely correspond to climatic changes in the adjacent Amazon basin, the proximate source of water for the northern Altiplano (see Cross et al., 2000). Our long-term aim is to understand better the hydrologic history of Lake Titicaca and the significance of that history in terms of regional and global hydrologic and climatic changes. A continuous record of the secular variation of $\delta^{18} \mathrm{O}$ of Altiplano precipitation in the past 25,000 years has been obtained from the Sajama ice cap (Thompson et al., 1998). Here we employ an isotopic and chemical model in order to assess the magnitude of hydrologic changes required to produce the observed lake-level changes and to investigate the expected isotopic and chemical response of the lake to water-balance changes.

\section{Setting}

The Altiplano (Figure 1) is a large interior drainage basin within the Andes, encompassing parts of Peru, Bolivia, and Chile. Lake Titicaca (approximately $16^{\circ} \mathrm{S}, 69^{\circ} \mathrm{W}$ ) is situated at an elevation of $3,810 \mathrm{~m}$ at the northern end of the Altiplano. The area of the watershed for Lake Titicaca (the northern portion of the Altiplano) is approximately $57,500 \mathrm{~km}^{2}$ and includes the Quelccaya ice cap located about $150 \mathrm{~km}$ north of the lake. The Sajama ice cap (Thompson et al., 1998) is located on the Altiplano $200 \mathrm{~km}$ southwest of the lake.

The modern lake comprises two nearly separate basins: the smaller Lago Huiñaimarca $\left(1,428 \mathrm{~km}^{2}\right.$; mean depth $=10 \mathrm{~m}$; max depth $=40 \mathrm{~m})$ and Lago Grande $\left(7,131 \mathrm{~km}^{2}\right.$; mean depth $=100 \mathrm{~m}$; max depth $=285 \mathrm{~m}$ ). The two basins are connected by the Strait of Tiquina, which is approximately $1-\mathrm{km}$ wide and has a sill depth of $35 \mathrm{~m}$ below modern lake level. A single outlet for the lake, the Río Desaguadero, drains out the southern end of Lago Huinaimarca to the central Altiplano. The Río Desaguadero outlet is silled at approximately $3,804 \mathrm{~m}$ above sea level, about $5 \mathrm{~m}$ below the 20th-century mean lake level. Additional information on the modern limnology of the lake is available in Dejoux and Iltis (1992).

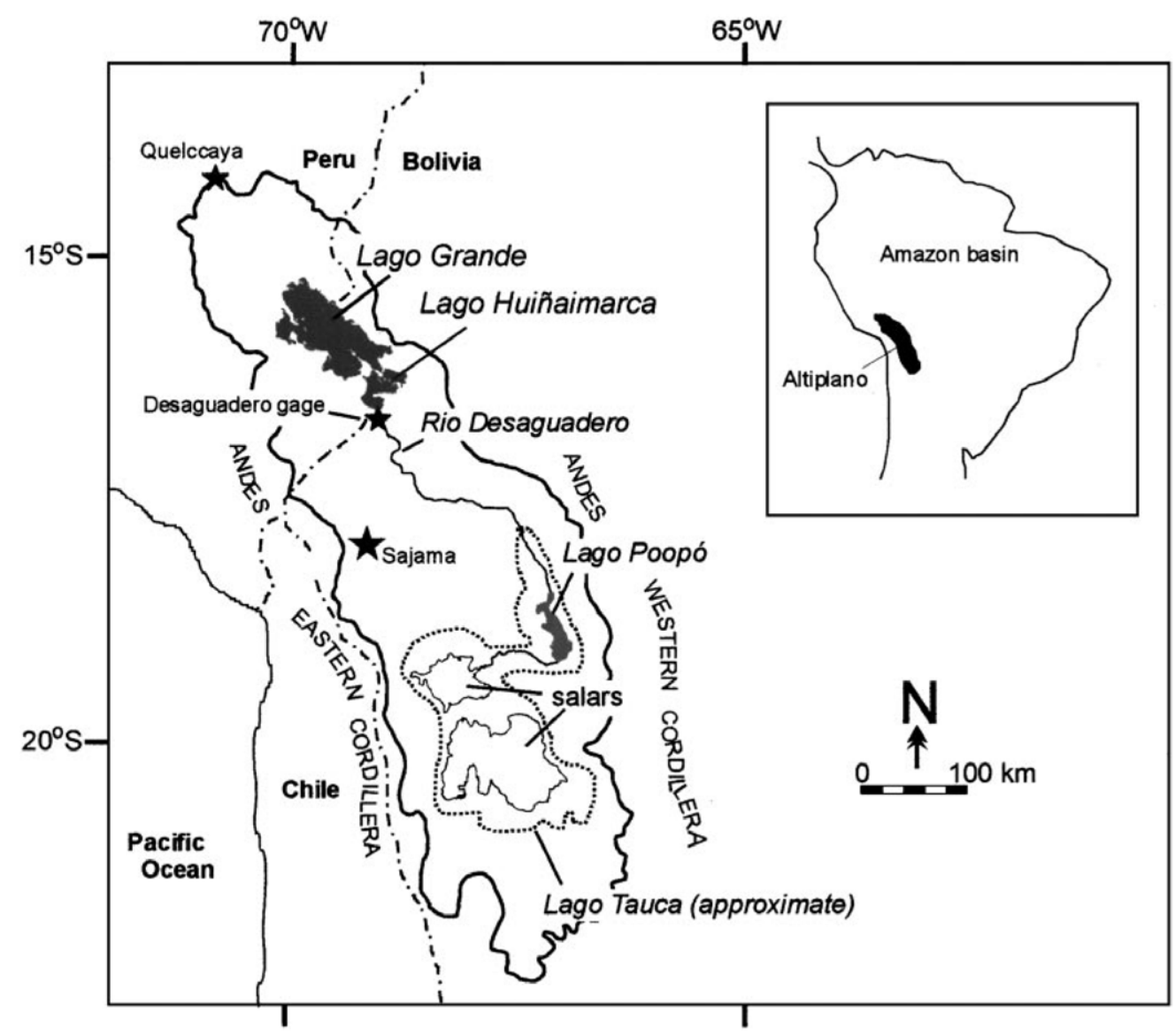

Figure 1. Lake Titicaca and the Bolivian/Peruvian Altiplano. 
The Lake Titicaca watershed receives $880 \mathrm{~mm}$ of precipitation per year on average (data from Servicio Nacional de Meteorologia y Hidrologia de Peru y Bolivia [SENAMHI]). About $80 \%$ of the total annual rainfall occurs in the summer months, from December through March. Although the Altiplano is near the Pacific Ocean, climatological (Johnson, 1976; Ratisbona, 1976) and isotopic (Grootes et al., 1989) studies show that the principal moisture source for the northern Altiplano is the Amazon Basin to the north and east.

The water balance of Lake Titicaca has been studied hydrologically (Roche et al., 1992) and isotopically (Fontes et al., 1979). Based on approximately 30 years of data on riverine inflow and outflow, rainfall, and lake level, Roche et al. (1992) reported that an average of $53 \%$ of the total annual water input to the lake is from riverine input and $47 \%$ from direct precipitation onto the lake; evaporation accounts for $91 \%$ of the water loss, and outflow from the Desaguadero accounts for the remaining 9\%. Fontes et al. (1979) reported a similar budget based on an oxygen isotope mass balance. Using $\delta^{18} \mathrm{O}$ measurements on lake water and river inflow, Fontes et al. (1979) determined that evaporation accounts for between $93 \%$ and $100 \%$ of the loss of water from the modern lake. The modern lake, therefore, is close to being hydrologically closed, and instances of flow reversal in the Desaguadero, indicating total basin closure, have been recorded (Roche et al., 1992).

Lake level varies significantly on seasonal and longer time scales. The amplitude of the seasonal lake-level change, from a nearly 90-yr record from Puno, Peru (SENAMHI Peru, unpublished data), averages $\sim 0.7 \mathrm{~m}$, with the highest levels generally occurring in April (corresponding to the end of the wet season and peak river discharge) and the lowest levels in December, prior to the beginning of the wet season. The seasonal change in lake level is asymmetric, with a relatively rapid rise and slower fall. The total range of lake level over the period of record is $6.4 \mathrm{~m}$, representing a volume change of about $6 \%$ for the lake as a whole and a volume change of $33 \%$ for Lago Huiñaimarca (Roche et al., 1992).

There have been several studies of the hydrology of paleolake systems on the Altiplano (Kessler, 1984; Hastenrath and Kutzbach, 1985; Binford et al., 1997; Blodgett et al., 1997). Hastenrath and Kutzbach (1985) modeled surface energy and water budgets to study the conditions that produced Lake Tauca; they concluded that a precipitation increase of 50-75\% was required. Blodgett et al. (1997) approached the same problem using a model that combined energy-budget and bulk-transfer methods. They calculated that a $10^{\circ} \mathrm{C}$ temperature drop, a doubling of cloud cover, or a $50 \%$ increase in precipitation could have produced the great paleolake. Binford et al. (1997) applied the Hastenrath and Kutzbach (1985) model to examine a late-Holocene lowstand of Lake Titicaca linked to human cultural collapse. They calculated that a 15\% decrease in precipitation could have lowered lake level by 12 to $17 \mathrm{~m}$.

\section{Model Description}

The oxygen isotope mass balance of Lake Titicaca is described by

$$
\begin{array}{r}
d\left\{V \delta_{\text {lake }}\right\} / d t=\delta_{\text {rain }} Q_{\text {rain }}+\delta_{\text {inflow }} Q_{\text {inflow }}- \\
\delta_{\text {evap }} Q_{\text {evap }}- \\
\delta_{\text {ouflow }} Q_{\text {outflow }}
\end{array}
$$

where $V$ equals lake volume, $\delta_{i}$ represents the isotopic composition of component $i$, and $Q_{i}$ represents the mass flux of component $i$.

Likewise, the mass balance of chloride is represented by

$$
\left.d\left\{\mathrm{VCCl}^{-}\right]_{\text {lake }}\right\} / d t=\left[\mathrm{Cl}^{-}\right]_{\text {inflow }} Q_{\text {inflow }}-\left[\mathrm{Cl}^{-}\right]_{\text {outflow }} Q_{\text {outflow }}
$$

where $\left[\mathrm{Cl}^{-}\right]_{i}$ represents the chloride concentration in component $i$, assuming chloride is conservative and that gains by precipitation and losses by evaporation are not important. These represent the governing equations of a box model constructed with the STELLA software package (High Performance Systems Software, Inc.) that solves the equations using a secondorder Runge-Kutta numerical scheme.

Model inputs, derived from our own isotopic and chemical data, as well as data from other sources, are summarized in Table 1. Values for rain and river water fluxes are taken from

\begin{tabular}{|c|c|c|}
\hline Symbol & Description & Value \\
\hline$Q_{\text {inflow }}$ & River water input & $8.51 \times 10^{9} \mathrm{~m}^{3} \mathrm{yr}^{-1 a}$ \\
\hline$Q_{\text {rain }}$ & Rain water input onto lake surface & $7.48 \times 10^{9} \mathrm{~m}^{3} \mathrm{yr}^{-1 a}$ \\
\hline$Q_{\text {outflow }}$ & Lake outflow via the Río Desaguadero & $1.60 \times 10^{9} \mathrm{~m}^{3} \mathrm{yr}^{-1 a}$ \\
\hline$\delta_{\text {inflow }}$ & $\begin{array}{l}\text { Average isotopic composition } \\
\text { of river inflow }\end{array}$ & $-14.4 \%^{a}$ \\
\hline$\delta_{\text {rain }}$ & $\begin{array}{l}\text { Isotopic composition of rainfall } \\
\text { onto lake surface }\end{array}$ & $-17.5 \%{ }^{a}$ \\
\hline$\left[\mathrm{Cl}^{-}\right]_{\text {lake }}$ & $\begin{array}{l}\text { Lake chloride concentration } \\
\quad \text { (initial) }\end{array}$ & $1.51 \times 10^{-3} \mathrm{~mol} \mathrm{~kg}^{-1}$ \\
\hline$\left[\mathrm{Cl}^{-}\right]_{\text {inflow }}$ & $\begin{array}{l}\text { Average chloride concentration } \\
\text { of river inflow }\end{array}$ & $1.51 \times 10^{-3} \mathrm{~mol} \mathrm{~kg}^{-1}$ \\
\hline$T_{\text {lake }}$ & Temperature of lake surface water & $13.0^{\circ} \mathrm{C}^{a}$ \\
\hline$T_{\text {air }}$ & Air temperature & $8.2^{\circ} \mathrm{C}^{a}$ \\
\hline$h$ & Relative humidity & 0.57 \\
\hline$U$ & Windspeed at $10 \mathrm{~m}$ above lake surface & $3.28 \mathrm{~m} \mathrm{~s}^{-1}$ \\
\hline G & Global radiation & $340 \mathrm{~W} \mathrm{~m}^{-2 b}$ \\
\hline$c$ & Cloud fraction & $0.35^{b}$ \\
\hline$\alpha$ & Albedo of lake surface & $0.6^{b}$ \\
\hline$B$ & Bowen ratio & $0.2^{b}$ \\
\hline
\end{tabular}

Table 1 Model Input Parameters

${ }^{a}$ Parameters that are varied between or within model runs. In this case, the value given is that for modern mean annual conditions.

${ }^{b}$ Parameters that are used only in the heat-budget model for evaporation. $G$, $c$, and $\alpha$ are used to calculate $R_{\text {net }}$, the net radiation at the lake surface (Equation 4). See Hastenrath and Kutzbach $(1983,1985)$ for details. 
instrumental records for the period 1957-1990. Evaporation is calculated from a semi-empirical formula (Pickard and Emery, 1990),

$$
Q_{\text {evap }}\left(\mathrm{kg} \mathrm{m}^{-2} \text { day }^{-1}\right)=(1: 4 \times \mathrm{U})\left(s_{\mathrm{T}, \mathrm{w}}-h \times s_{\mathrm{T}, \mathrm{a}}\right)
$$

where $U$ is windspeed at $10 \mathrm{~m}$ above the lake surface, $h$ is relative humidity, and $s$ is saturation vapor pressure at the temperature of the water $(T, w)$ or air $(T, a)$. Lake-surface and air temperatures and humidity come from modern recorded values. Accurate values for windspeed over the lake are lacking. Han's (1995) model of Lake Titicaca used a value for mean annual windspeed of $1.15 \mathrm{~m} \mathrm{~s}^{-1}$, based on the work of Roche et al. (1992). Blodgett et al. (1997) used a value of $4.6 \mathrm{~m} \mathrm{~s}^{-}$ ${ }^{1}$ in their model of the Pleistocene water balance of the Altiplano. This value was derived from measurements of windspeed over modern Lake Titicaca reported by Kirkish and Taylor (1984); Blodgett et al. (1997) argued that windspeeds are typically two to three times lower on land than over the lake. A reasonable value for windspeed is derived by calculating the evaporation required to maintain constant lake volume, using as inputs the mean values for river inflow, precipitation, and river outflow for the period 1957-1990 (over which time there has been little net storage). Mean annual windspeed thus derived is $3.8 \mathrm{~m} \mathrm{~s}^{-1}$, well within the reported range.

Using this value for windspeed, a model of the seasonal behavior of the lake was constructed using 12-month time series of hydrological and climatological inputs representing monthly mean values derived from historical data. Lake level is calculated from the model-derived lake volume, based on the hypsometry of the lake basin (from Wirrmann et al., 1992). The model reproduces the observed seasonally asymmetric pattern of lake level, with maximum levels in April, minimum levels in December, and an amplitude of $0.74 \mathrm{~m}$ (Figure 2).

Because of uncertainties in choosing windspeed and the sensitivity of the model to that quantity, we also calculated evaporation using the heat-budget method for comparison,

$$
Q_{\text {evap }}\left(\mathrm{mm} \mathrm{yr}^{-1}\right)=R_{\text {net }} /[(1+B) \times L]
$$

where $R_{\text {net }}$ is net (shortwave minus longwave) radiation at the lake surface, $B$ is the Bowen ratio, and $L$ is the latent heat of evaporation (Hastenrath and Kutzbach 1983, 1985). This model requires inputs for water and air temperatures, relative humidity, Bowen ratio, surface albedo, and cloud fraction (see Table 1). Measured values of temperature and humidity are available, and we adopt values for Bowen ratio and albedo from Hastenrath and Kutzbach (1985). Cloud fraction is an important component of the model through its effects on both longwave and shortwave radiation. Previous authors have used values between 0.11 (Binford et al. 1997) and 0.5 (Hastenrath and Kutzbach, 1985) in their energy-budget models of Altiplano lake systems. We use the modern hydrologic budget to calculate a modern value for cloud fraction, analogous to our approach for windspeed, described above. The value thus

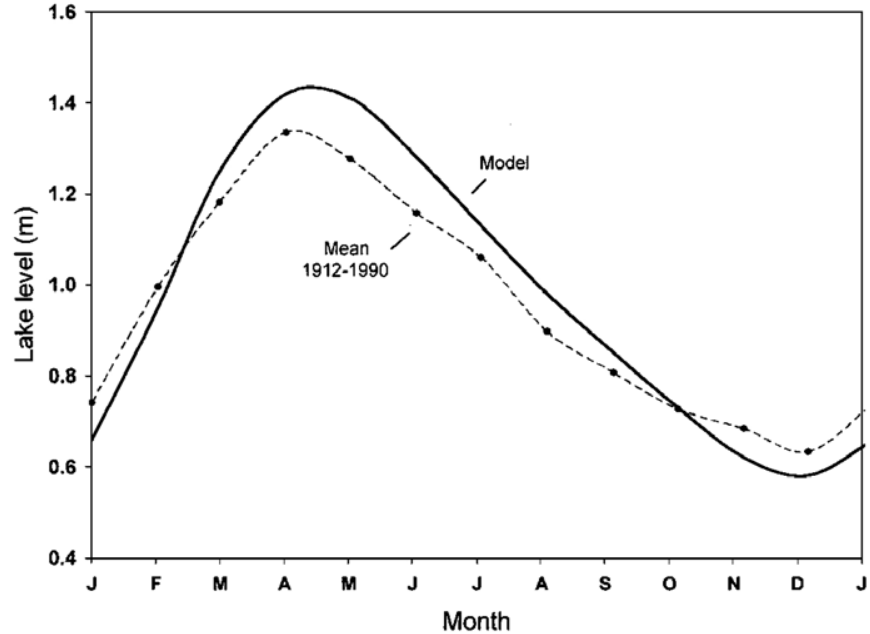

Figure 2. A one-year model simulation of lake level, using historical data for inputs of rainfall, river inflow, river outflow, water and air temperature, and humidity. A time series of monthly mean lake level (meters above a 3,809-m datum) for the period 1912-1990 is plotted for comparison (data from Servicio Nacional de Meteorologia y Hidrologia de Peru).

derived is 0.35 , midway between the previous workers' values. This value is used in all simulations.

Neither evaporation model calculates the effect of increasing air temperature on lake surface temperature. The difference between lake and air temperatures has a direct effect on the calculated vapor-pressure gradient and therefore on evaporation. Equal forcing was applied to the lake surface temperature and to air temperature, so that the air-water temperature difference in all runs was equal to the modern observed value $\left(4.8^{\circ} \mathrm{C}\right)$. The sensitivity of the model to this difference and to other poorly known quantities is examined in a later section.

Input values for oxygen isotopic ratios were taken from our unpublished data or were calculated by the model. The value of $-14.4 \%$, chosen for river input, represents a mean of our measured values of riverine $\delta^{18} \mathrm{O}$ for the five major inflowing rivers, weighted by mean annual inflow recorded for the period 1956-1987. In our data from 1995 to $1998, \delta^{18} \mathrm{O}$ values of Lago Grande varied between -4.16 and $-4.56 \%$ for surface water and was between -4.40 and $-4.43 \%$ for waters from 250 and $270 \mathrm{~m}$ depth ( $n=15$, Table S1). Fontes et al. (1979) reported values ranging from -3.8 to $-4.4 \%$ for Lago Grande; these numbers represent averages over the depth range 0 to $200 \mathrm{~m}$ on samples taken between June of 1976 and March of 1977. A value of $-4.2 \%$ was chosen as representative of the modern lake (Lago Grande) surface water.

The model calculates the isotopic composition of evaporating water according to the formula of Merlivat and Jouzel (1979),

$$
\delta^{18} \mathrm{O}_{\mathrm{V}}=\left(1+10^{-3} \times \delta^{18} \mathrm{O}_{\mathrm{L}}\right) \times(1-k) /\left[\left(1+10^{-3} \times e\right)(1-k h)\right]
$$


where $\delta^{18} \mathrm{O}_{\mathrm{V}}$ and $\delta^{18} \mathrm{O}_{\mathrm{L}}$ are respectively the isotopic compositions of the evaporating vapor and of the lake, $e$ is the equilibrium isotopic enrichment factor (calculated according to Friedman and O'Neil, 1977), $k$ is a constant accounting for diffusive and turbulent transport of an isotopic species away from the surface, and $h$ is relative humidity.

There are no long-term averaged data on the isotopic composition of rain falling on the lake. The model calculates a value for rainfall by solving Equation (1) for $\delta_{\text {rain }}$, assuming an equilibrium value of $-4.2 \%$ for $\delta_{\text {lake }}$. The resulting value is $-17.5 \%$, close to the value for long-term, near-modern precipitation on the Quelccaya and Sajama ice caps (Thompson et al., 1985, 1998). Fontes et al. (1979) estimated a value for $\delta_{\text {rain }}$ of $-17 \%$ by crossing an evaporation line based on $\delta \mathrm{D}$ and $\delta^{18} \mathrm{O}$ measurements on lake, wetland, and river water in the Lake Titicaca basin, with the meteoric water line. Finally, we have analyzed groundwater from several wells and springs on islands in the lake; the average of the $\delta^{18} \mathrm{O}$ values of these samples is $-16.1 \%$ o $(n=8$, Table S1). Thus, the model-derived estimate of $-17.5 \%$ for the $\delta^{18} \mathrm{O}$ of modern rainfall appears to be a reasonable approximation. Outflow from the Río Desaguadero is calculated according to an empirical relationship between lake level (volume) and riverine discharge gauged at the outlet at Desaguadero, Bolivia, between 1956 and 1987.

\section{Model Experiments and Results}

\section{Holocene Hydrologic Change}

To quantify the hydrologic change that caused the major early-Holocene drop in lake level, the model was used to calculate the changes in precipitation and temperature required to produce lake-level drops of 50 and $100 \mathrm{~m}$. We made a series of 2,500-yr simulations, each starting with modern values for (annualized) river inflow, precipitation, outflow, lake-surface and air temperatures, humidity, and windspeed. At model year 500 , the river and precipitation inputs were decreased in a single step, and temperature was increased or allowed to remain constant. The length of each simulation was sufficient for the lake to establish equilibrium at a lower level. The process was repeated until a number of solutions were obtained for 50- and 100-m lake-level drops at different temperatures.

With no temperature change, both evaporation treatments yield the same results: a $34 \%$ decrease in inputs from modern levels is required to produce a $50-\mathrm{m}$ drop in lake level, and a $43 \%$ decrease in inputs is required to produce a $100-$ $\mathrm{m}$ drop (Figure 3). These figures change to $21 \%(-50 \mathrm{~m})$ and $32 \%(-100 \mathrm{~m})$ for a temperature increase of $3{ }^{\circ} \mathrm{C}$ using the empirical evaporation treatment. The heat-budget evaporation treatment is relatively insensitive to temperature change; the required decrease in inputs to produce either a $50-\mathrm{m}$ or $100-\mathrm{m}$ lake-level drop given a $3{ }^{\circ} \mathrm{C}$ temperature increase is within a few tenths of a percent of the values for no temperature change. Some studies suggest that the early or middle Holocene was perhaps $1{ }^{\circ} \mathrm{C}$ warmer than today in the central Andes (Thompson et al., 1995). In this case, inputs to the

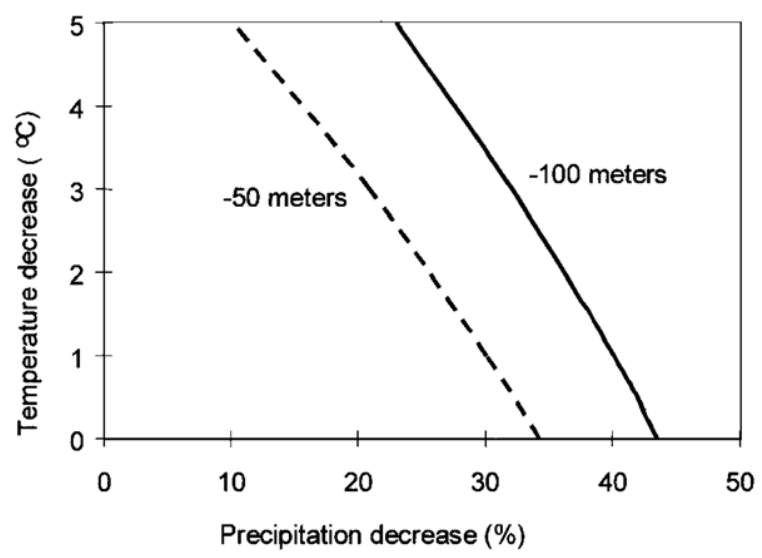

Figure 3. Model-calculated lake-level decrease as a function of water input and air temperature change.

lake must have been reduced by approximately $40 \%$ to lower the lake by $100 \mathrm{~m}$.

These model runs establish that the isotopic composition of the lake, although sensitive to changes in the water budget when the lake is close to overflow, rapidly reaches a steady-state value once the basin becomes closed. For example, a change in lake level from modern (slightly overflowing) to $-5 \mathrm{~m}$ (closed) yields an increase in $\delta_{\text {lake }}$ of about $2 \%$, while a further lake-level decrease to $-100 \mathrm{~m}$ results in only a $0.5 \%$ increase in $\delta_{\text {lake }}$. These results agree with conclusions of other workers that, in closed-basin lakes, $\delta_{\text {lake }}$ reaches a steady state as the composition of the water evaporated from the lake evolves to equal the composition of the inputs (Gat, 1984, 1995; Ricketts and Johnson, 1996).

\section{Isotopic and Chemical Changes}

The model was also used to investigate the isotopic and chemical composition of the lake during the period 15,000 cal yr B.P. to present, spanning the late-glacial highstand and early-to-middle Holocene lowstand intervals. We ran a 15,000-year simulation with forcing designed to reproduce the major changes in lake level that we have reconstructed based on our studies of piston cores from deep Lago Grande (Cross et al., 2000; Baker et al., 2001), ice-core records from Sajama (Thompson et al., 1998), correlation with the Lago Junin sediment record (Seltzer et al., 2000), and model studies of the central Altiplano (Blodgett et al., 1997). Because the Sajama ice cap is near Lake Titicaca, and because their modern precipitation is similar in $\delta^{18} \mathrm{O}$, the ice cap probably records the $\delta^{18} \mathrm{O}$ of precipitation that fed Lake Titicaca throughout the past 25,000 years. If so, changes in precipitation, evaporation, and temperature can be estimated without the confounding effect of variable $\delta_{\text {rain }}$.

For this simulation, the model treatment of water outflow was simplified to accommodate conditions, for which there are no appropriate river-gauge records, that were much wetter than those at present. The empirical relationship between lake level and discharge at the outlet was abandoned, and water in excess of the modern mean lake volume was allowed to freely 
discharge. For lake volumes equal to or less than the modern value, outflow was set at zero. The initial water input levels were set to $20 \%$ above the modern levels to simulate precipitation conditions that we believe are most reasonable for the late Pleistocene Tauca lacustrine phase on the Altiplano (Blodgett et al., 1997, their Figure 9a, assuming temperatures $5{ }^{\circ} \mathrm{C}$ lower than modern as in, for example, Hostetler and Mix, 1999). Under these conditions, flow out the Desaguadero increased to approximately 8 times greater than at present.

The isotopic composition of the inputs was initially depleted by $5 \%$ relative to modern values and was increased by $5 \%$ at $11,500 \mathrm{cal}$ yr B.P., consistent with data from the Sajama ice core (Thompson et al., 1998). Initial $\delta_{\text {lake }}$ was set at $-13.3 \%$, the equilibrium value given the initial hydrologic and isotopic inputs. The oxygen isotopic composition of the outflow was set equal to $\delta_{\text {lake }}$ throughout the run. The initial chloride mass in the lake was set to the modern level and the chloride concentration of the inflow was set to the observed modern mean value. Although the temperature history of the Altiplano is unknown in detail (see Ybert, 1992, for one interpretation), we assumed for the sake of modeling that snowline depressions and sea-surface temperature decreases of the last glacial maximum also applied to the latest Pleistocene; we therefore initialized air and lake-surface temperatures at $5{ }^{\circ} \mathrm{C}$ colder than present annual mean temperatures, consistent with the model results of Hostetler and Mix (1999).

The model was forced by changes in rates and isotopic compositions of hydrologic inputs and by changes in air and lake temperatures. At 11,500 cal yr B.P., the time when sedimentary records from Lake Titicaca show clear signs of decreased precipitation-to-evaporation ratio, the river and rain inputs were decreased to produce an equilibrium lake level of $-100 \mathrm{~m}$, simulating the onset of the Holocene dry period. At 5,000 cal yr B.P. the hydrologic inputs were increased at a constant rate, filling the lake to its present, just-overflowing level at 2,000 cal yr B.P. The sedimentary record shows that Lago Grande became fresher at this time, that evaporation decreased, and that Río Desaguadero again drained Lake Titicaca (Baucom and Rigsby, 1999). A short-term period of overflow that occurred between 10,000 and 8,500 cal yr B.P. (Baker et al., 2001) was not modeled. The isotopic composition of the inputs was increased by $5 \%$ to modern values at $11,500 \mathrm{cal}$ yr B.P. Temperatures were increased by $5{ }^{\circ} \mathrm{C}$ at $11,500 \mathrm{cal}$ yr B.P. according to some interpretations of the paleoclimatic record in the region. None of the major conclusions that we derive from the model are critically dependent upon this assumed temperature. Each forcing was applied in a single step (except the ramped increase in moisture between 5,000 and 2,000 cal yr B.P.).

In this simulation the $\delta_{\text {lake }}$ value jumps from its initial late Pleistocene overflow condition in response to the decreased input and the $5 \%$ increase in $\delta_{\text {rain }}$, reaching a maximum value of about $-0.6 \%$ before relaxing to a steady-state, early-Holocene value of $-1.9 \%$. At the end of the dry interval, $\delta_{\text {lake }}$ decreases irregularly (because of hypsometry-related evaporation effects) to its final (near-modern) value of $-3.9 \%$ (Figure 4.).
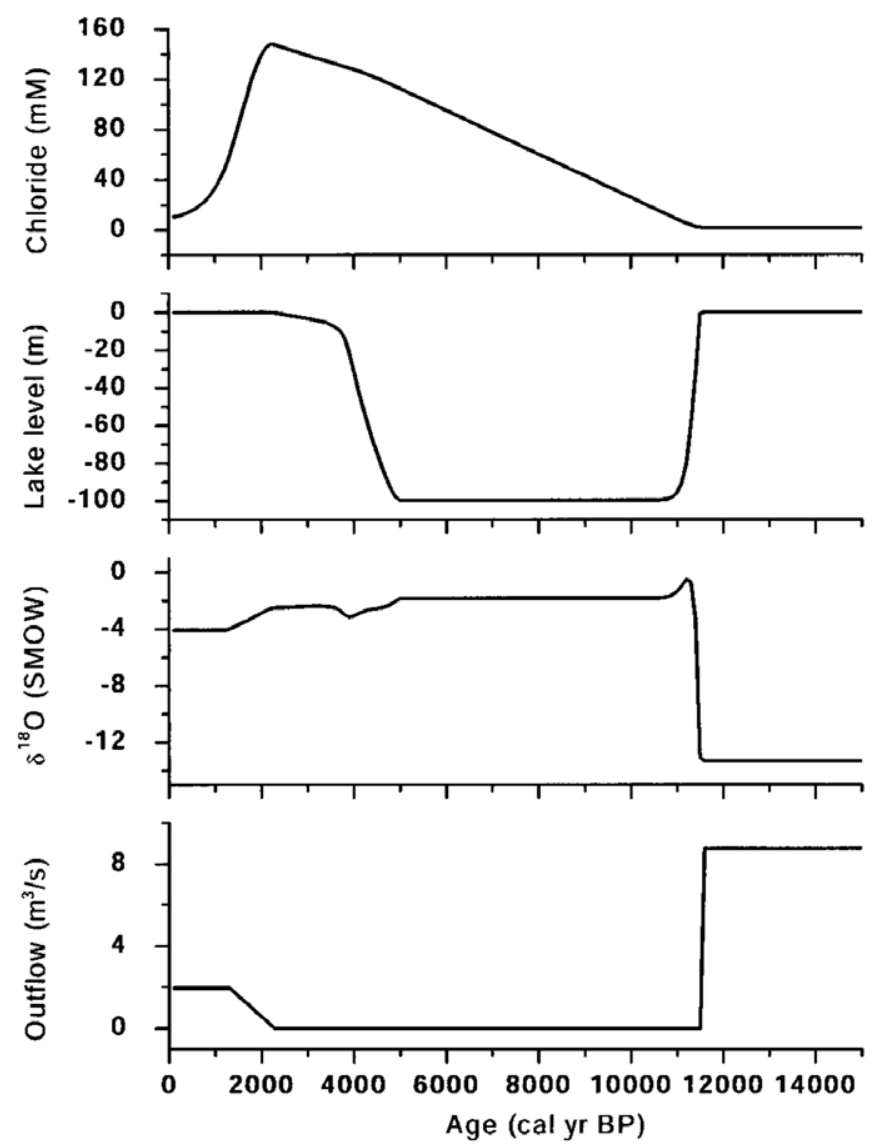

Figure 4. Fifteen-thousand-year simulation of lake level, $\delta^{18} \mathrm{O}$ of lake water, chloride concentration of lake waters, and water discharge via the Río Desaguadero.

The lake's steady-state isotopic composition during the Holocene lowstand is the same $(-1.9 \%)$ for both evaporation treatments, because under closed-basin and steady-state conditions the ratio of river input to precipitation input controls the lake isotopic composition; this ratio is part of the forcing and does not depend on the evaporation model. However, the steady-state value during the late Pleistocene overflow conditions is substantially greater $(-10.5 \%$ ) with the heat-budget evaporation model than with the empirical evaporation model $(-13.3 \% 0)$.

Chloride concentrations rose to about $0.15 \mathrm{~mol} \mathrm{~kg}^{-1}$ by the end of the closed-lake interval (2,000 cal yr B.P.) and then fell rapidly once the lake began to overflow at its outlet. Similar behavior of other conservative ions, such as sodium, can be expected. The final value for the simulated chloride concentration of lake waters was $0.01 \mathrm{~mol} \mathrm{~kg}^{-1}$, still several times greater than the observed modern value, but not a steady-state value, as chloride was still decreasing at the end of the model run.

\section{Model Sensitivity}

The model results depend on some quantities that are unknown or poorly known. In particular, lake surface temperature, windspeed, humidity, and cloud fraction all affect evaporation 
Table 2. Sensitivity Analysis

\begin{tabular}{lcc}
\hline Parameter & Change & Result \\
\hline$\Delta T_{\text {lake }}$ & $0.5 \times \Delta T_{\text {air }}$ & $Q_{\text {evap }}$ decreases by $6 \%$ \\
$\Delta T_{\text {lake }}$ & $0.75 \times \Delta T_{\text {air }}$ & $Q_{\text {evap }}$ decreases by $3 \%$ \\
$h$ & $-10 \%$ & $Q_{\text {evap }}$ increases by $7 \%$ \\
$h$ & $-10 \%$ & $\delta_{\text {lake }}$ increases by $0.4 \%$ \\
$U$ & $-10 \%$ & $Q_{\text {evap }}$ decreases by $10 \%$ \\
$C$ & $-10 \%$ & $Q_{\text {evap }}$ increases by $4 \%$ \\
\hline
\end{tabular}

(in one or both of the evaporation treatments) and, ultimately, the calculated lake-level change. The sensitivity of the model to changes in windspeed, humidity, and cloud fraction was determined by additional model runs in which the parameter in question was decreased by $10 \%$ concurrent with the step changes in hydrologic and climatologic inputs (Table 2). Humidity also has a large effect on $\delta_{\text {lake }}$ through its effect on the isotopic composition of evaporating water vapor (Equation 4). The equilibrium closed-lake $\delta_{\text {lake }}$ was enriched by about $0.4 \%$ by the $10 \%$ humidity decrease.

The calculated evaporation rate is sensitive to the temperature difference between the lake surface and the overlying air (Equation 3). In our simulation, the lake surface water temperature increases by the same amount as the air temperature (1 ${ }^{\circ} \mathrm{C}$ ) during the lowstand interval (i.e., $\Delta T_{\text {lake }}=\Delta T_{\text {air }}$ ). In reality, increased evaporative cooling of the lake surface during the lowstand may have reduced the air-water temperature difference, resulting in a lower calculated evaporation rate than that derived from the original assumption. We measured the sensitivity of the model to the air-water temperature difference by additional model runs in which the lake surface warmed less than the air. For $\Delta T_{\text {lake }}=0.5 \Delta T_{\text {air }}$ there is a $6 \%$ decrease in evaporation relative to the original calculation; for $\Delta T_{\text {lake }}=$ $0.75 \Delta T_{\text {air }}$ there is a $3 \%$ decrease (Table 2).

\section{Discussion}

The results of this study combined with earlier hydrologic modeling suggest that precipitation may have decreased by half on the northern Altiplano between the late glacial period and early Holocene. A lake-level fall of 50 to $100 \mathrm{~m}$ in the early Holocene required a sustained precipitation decrease of $30 \%$ to $40 \%$ relative to today's, while the late Pleistocene Tauca lacustrine phase on the Altiplano required a precipitation increase of $20 \%$ (Blodgett et al., 1997, assuming $5{ }^{\circ} \mathrm{C}$ lower temperatures) to $75 \%$ more than modern levels (Kessler, 1984; Hastenrath and Kutzbach, 1985). The two combined suggest late glacial values of perhaps $1,000 \mathrm{~mm} \mathrm{yr}^{-1}$, dropping to early Holocene values of perhaps $500 \mathrm{~mm} \mathrm{yr}^{-1}$. The higher levels of precipitation during the latest Pleistocene mean that Lake Titicaca was a deep, fresh, and overflowing lake at that time. Discharge at the outlet averaged about 8 times its modern mean value. This overflow, in turn, was a substantial, and possibly dominant, contribution of inflow to paleolake Tauca on the central Altiplano. When the dry period set in around 11,500 cal yr B.P., Lake Titicaca fell below its outlet, the water supply to the central Altiplano via the Desaguadero was cut off, and paleolake Tauca rapidly desiccated as local precipitation and runoff decreased.

As long as Lake Titicaca remained below its outlet level, salinity increased. The modern-day residence times for the mostly conservative ions- $\mathrm{Na}^{+}, \mathrm{K}^{+}, \mathrm{Sr}^{2+}, \mathrm{Mg}^{2+}, \mathrm{Cl}^{-}$, and $\mathrm{SO}_{4}{ }^{2-}$, for example-range from about 350 to $500 \mathrm{yr}$ (Carmouze et al., 1992); Lake Titicaca receives about $0.8 \mathrm{~g} \mathrm{~kg}^{-1}$ of conservative salt every $500 \mathrm{yr}$. If the lake was a closed basin for 9,500 years as in our simulation, it would have accumulated about $15 \mathrm{~g} \mathrm{~kg}^{-1}$, nearly one-half the salinity of seawater. The occurrence of an overflow interval between 10,000 and 8,500 cal yr B.P. (Baker et al., 2001) means that this salinity was likely never reached. However, our assumption that inflow chloride concentration remained at the same (modern) value throughout the simulation is conservative; the value may well have risen during the dry period, as it does seasonally today (Carmouze et al., 1992).

A problem with this or any model of paleohydrological conditions is its sensitivity to poorly known quantities. In particular, the semi-empirical treatment of evaporation is highly sensitive to windspeed, a quantity that is poorly known even for the modern lake. The heat-budget formulation for evaporation obviates this problem but introduces other unknowns, most importantly cloud fraction. In our model cloud fraction over the lake is a constant, but it could have been significantly lower during the Holocene dry period. Nevertheless, the similarity in evaporation calculated by the different approaches, especially considering that Holocene temperature variations were likely small, increases our confidence in the results.

One further drawback to this model is that it assumes that changes of lake level did not produce significant changes in the ambient climate (e.g., humidity or rainfall in the lake basin). This is an unrealistic assumption for a lake as large as Lake Titicaca (Taborga and Campos, 1995) and, as the model results are fairly sensitive to humidity, may be a significant source of error.

\section{Conclusions}

Using a simple box model we have investigated the magnitude of hydrologic change required to produce the large, earlyHolocene drop in lake that occurred in Lake Titicaca, as well as the nature of associated chemical and isotopic change. Our principal findings are as follows:

Assuming a precipitation increase of $20 \%$ during the latePleistocene Tauca lacustrine phase (based on the work of Blodgett et al., 1997), outflow from late-Pleistocene Lake Titicaca was approximately 8 times greater than the modern average, representing a substantial contribution of inflow to paleolake Tauca.

A $40 \%$ decrease in hydrologic inputs from modern mean values was required to produce a lake-level decline of $100 \mathrm{~m}$, 
assuming a $1{ }^{\circ} \mathrm{C}$ warming (relative to modern) during the early to middle Holocene and no change in mean annual windspeed. Fluctuations in the Holocene water budget of the northern Altiplano were thus apparently of the same order as those during the late Pleistocene.

The stable isotopic signal recorded in lake carbonates from the Holocene closed-basin interval should be small, although the transitions between open and closed conditions should produce a large signal.

Lake salinity reached a maximum just before the basin overflowed approximately 2,000 years ago. For a closed-basin interval of 9,500 years, the maximum salinity would approach half the seawater value.

\section{Acknowledgments}

We acknowledge the administration and scientists at Autoridad del Lago Titicaca including Ings. Mario Revollo, Julio Sanjines, Jaime Taborgo, and Julio Campos. Funding for this research was provided by NSF Grants ATM9619672 (to PAB), ATM9708258 (to GOS), ATM9896152 (to SCF), and ATM9996205 (to RBD). We thank S. Hastenrath and an anonymous reviewer for helpful comments on an earlier draft of this paper.

\section{References}

Abbott et al., 1997 - M. B. Abbott, M. W. Binford, M. Brenner, and K. R. Kelts, A $3500{ }^{14} \mathrm{C}$ yr high-resolution record of water-level changes in Lake Titicaca, Bolivia/Peru. Quaternary Research 47 (1997), pp. 169-180.

Baker et al., 1999 - P. A. Baker, C. A. Rigsby, N. P. Bacher, G. S. Dwyer, G. O. Seltzer, S. C. Fritz, and T. Lowenstein, Late Quaternary paleoclimate of tropical South America: First results from the drill-core record of the Salar de Uyuni, Bolivia. Eos, Transactions of the American Geophysical Union 80 (1999), p. F531.

Baker et al., 2001 - P. A. Baker, G. O. Seltzer, S. C. Fritz, R. B. Dunbar, M. J. Grove, P. M. Tapia, S. L. Cross, H. D. Rowe, and J. P. Broda, The history of South American tropical precipitation for the past 25,000 years. Science 291 (2001), pp. 640-643.

Baucom and Rigsby, 1999 - P. C. Baucom and C. A. Rigsby, Climate and lake-level history of the northern Altiplano, Bolivia, as recorded in Holocene sediments of the Río Desaguadero. Journal of Sedimentary Research 69 (1999), pp. 597-611.

Bills et al., 1994 - B. G. Bills, S. L. de Silva, D. R. Currey, R. S. Emenger, K. D. Lillquist, A. Donnellan, and B. Worden, Hydroisostatic deflection and tilting in the central Andes: Initial results of GPS survey of Lake Minchin shorelines. Geophysical Research Letters 21 (1994), pp. 293-296.

Binford et al., 1997 - M. W. Binford, A. L. Kolata, M. Brenner, J. W. Janusek, M. T. Seddon, M. Abbott, and J. H. Curtis, Climate variation and the rise and fall of an Andean civilization. Quaternary Research 47 (1997), pp. 235-248.

Blodgett et al., 1997 - T. Blodgett, J. Lenters, and B. Isacks, Constraints on the origin of paleolake expansions in the central Andes. Earth Interactions (1997), p. 1.
Carmouze et al., 1992 - J.-P. Carmouze, C. Arze, and J. Quintanilla, Hydrochemical regulation of the lake and water chemistry of its inflow rivers. In: C. Dejoux and A. Iltis, Editors, Lake Titicaca: A Synthesis of Limnological Analysis, Kluwer Academic, Dordrecht (1992), pp. 98-112.

Cross et al., 2000 - S. L. Cross, P. A. Baker, G. O. Seltzer, S. C. Fritz, and R. B. Dunbar, A new estimate of the Holocene lowstand level of Lake Titicaca $\left(16^{\circ} \mathrm{S}\right)$ and implications for regional paleohydrology. The Holocene 10 (2000), pp. 21-32.

Dejoux and Iltis, 1992 - C. Dejoux and A. Iltis. Lake Titicaca: A Synthesis of Limnological Analysis, Kluwer Academic, Dordrecht (1992).

Fontes et al., 1979 - J.-Ch. Fontes, B. Boulange, J. P. Carmouze, and T. Florkowski, Preliminary oxygen-18 and deuterium study of the dynamics of Lake Titicaca. Isotopes in Lake Studies: Proceedings of an Advisory Group Meeting on the Application of Nuclear Techniques to the Study of Lake Dynamics, Unipub, New York (1979) p. 145-150 .

Friedman and O’Neil, 1977 - G. M. Friedman and J. R. O'Neil, Compilation of stable isotope fractionation factors of geochemical interest. in Data of Geochemistry, U.S. Geological Survey Professional Paper 440M. Fleischer, Ed., pp. 1-12. United States Geological Survey.

Gat, 1984 - J. R. Gat, The stable isotope composition of Dead Sea waters. Earth and Planetary Science Letters 71 (1984), pp. 361-376.

Gat, 1995 - J. Gat, Stable isotopes of fresh and saline lakes. In: A. Lerman, D. Imboden and J. Gat, Editors, Physics and Chemistry of Lakes, Springer-Verlag, New York (1995), pp. 139-165.

Grootes, et al. 1989 - P. M. Grootes, M. Stuiver, L. G. Thompson, and E. Mosley-Thompson, Oxygen isotope changes in tropical ice, Quelccaya, Peru. Journal of Geophysical Research 94 (1989), pp. 1187-1194.

Han, 1995 - Y. Han. Stella-based Simulation of Oxygen and Carbon Isotopic Behavior of Lake Systems, University of Minnesota (1995).

Hastenrath and Kutzbach, 1983 - S. Hastenrath and J. Kutzbach, Paleoclimatic estimates from water and energy budgets of East African lakes. Quaternary Research 19 (1983), pp. 141-153.

Hastenrath and Kutzbach, 1985 - S. Hastenrath and J. Kutzbach, Late Pleistocene climate and water budget of the South American Altiplano. Quaternary Research 24 (1985), pp. 249-256.

Hostetler and Mix , 1999 - S. W. Hostetler and A. C. Mix, Reassessment of ice-age cooling of the tropical ocean and atmosphere. Nature 399 (1999), pp. 673-676.

Johnson, 1976 - A. M. Johnson, The climate of Peru. In: W. Schwerdtfeger, Editor, Climates of Central and South America, Elsevier, New York (1976), pp. 147-218.

Kessler, 1984 - A. Kessler, The palaeohydrology of the Late Pleistocene Lake Tauca on the Bolivian Altiplano and recent climatic fluctuations. In: J. C. Vogel, Editor, Late Cainozoic Palaeoclimates of the Southern Hemisphere, A. A. Balkema, Rotterdam (1984), pp. 115-122.

Kirkish and Taylor, 1984 - M. H. Kirkish and M. J. Taylor, Micrometeorological measurements at Lake Titicaca (Peru-Bolivia). Vehrhandlungen. Internationaler Vereinigung fuer Theoretische und Angewandt e Limnologie 22 (1984), pp. 1232-1236. 
Marengo and Hastenrath, 1993 - J. Marengo and S. Hastenrath, Case studies of extreme climatic events in the Amazon Basin. Journal of Climate 6 (1993), pp. 617-627.

Martin et al., 1997 - L. Martin, J. Bertaux, T. Correge, M. Ledru, P. Mourguiart, A. Sifeddine, F. Soubies, D. Wirrmann, K. Suguio, and B. Turcq, Astronomical forcing of contrasting rainfall changes in tropical South American between 12,400 and 8800 cal yr BP. Quaternary Research 47 (1997), pp. 117-122.

Merlivat and Jouzel, 1979 - L. Merlivat and J. Jouzel, Global climatic interpretation of the deuterium-oxygen 18 relationship for precipitation. Journal of Geophysical Research 84 (1979), pp. 5029-5033.

Mourguiart et al., 1995 - Ph. Mourguiart, J Argollo, P. Carbonel, T. Correge, and D. Wirrmann, El lago Titicaca durante el Holoceno: Una historia compleja. In: J. Argollo and Ph. Mourguiart, Editors, Cambios cuaternarios en America del Sur, ORSTOM, La Paz (1995), pp. 173-188.

Pickard and Emery, 1990 - G. L. Pickard and W. J. Emery. Descriptive Physical Oceanography, Pergamon Press, Oxford (1990).

Ratisbona, 1976 - L. R. Ratisbona, The climate of Brazil. In: W. Schwerdtfeger, Editor, Climates of Central and South America, Elsevier, New York (1976), pp. 219-294.

Ricketts and Johnson, 1996 - R. D. Ricketts and T. C. Johnson, Climate change in the Turkana basin as deduced from a 4000 year long $\delta^{18} \mathrm{O}$ record. Earth and Planetary Sciences Letters 142 (1996), pp. 7-17.

Roche et al., 1992 - M. A. Roche, J. Bourges, J. Cortes, and R. Mattos, Climatology and hydrology of the Lake Titicaca basin. In: C. Dejoux and A. Iltis, Editors, Lake Titicaca: A Synthesis of Limnological Knowledge, Kluwer Academic, Dordrecht (1992), pp. 63-88.

Seltzer et al., 1998 - G. Seltzer, P. Baker, S. Cross, R. Dunbar, and S. Fritz, High-resolution seismic reflection profiles from Lake Titicaca, Peru/Bolivia: Evidence for Holocene aridity in the tropical Andes. Geology 26 (1998), pp. 167-170.

Seltzer et al., 1999 - G. O. Seltzer, P. A. Baker, S. C. Fritz, and R. B. Dunbar, Late Quaternary lake level variation in the Peruvian-Bolivian Altiplano. Eos, Transactions American Geophysical Union 80 (1999), p. F4.

Seltzer et al., 2000 - G. O. Seltzer, D. Rodbell, and S. J. Burns, Isotopic evidence for late Quaternary climatic change in tropical South America. Geology 28 (2000), pp. 35-38.

Servant et al., 1978 - M. Servant and J.-C. Fontes, Les lacs quaternaires des hauts plateaux des Andes boliviennes, premieres interpretations paleoclimatiques. Cahiers ORSTOM, Serie Geologie 10 (1978), pp. 9-24.

Servant et al., 1995 - M. Servant, M. Fournier, J. Argollo, S. Servant-Vildary, F. Sylvestre, D. Wirrmann, and J.-P. Ybert, La derniere transition glaciaire/interglaciaire des Andes tropicales sud (Bolivie) d'apres l'etude des variations des niveaux lacustres et des fluctuations glaciaires. Comptes rendues de l'Academie des sciences. 320 (1995), pp. 729-736.

Sylvestre et al., 1999 - F. Sylvestre, M. Servant, S. Servant-Vildary, C. Causse, M. Fournier, and J.-P. Ybert, Lake-level chronology on the southern Bolivian Altiplano $\left(18-23^{\circ} \mathrm{S}\right)$ during late-glacial time and the early Holocene. Quaternary Research 51 (1999), pp. 54-66.

Taborga and Campos, 1995 - J. Taborga and J. Campos, Recursos hydricos en los Andoes: Lago Titicaca. Bulletin del Institute Francaises des etudes Andines 24 (1995), pp. 441-448.

Thompson et al., 1998 - L. G. Thompson, M. E. Davis, E. MosleyThompson, T. Sowers, K. A. Henderson, V. S. Zagorodnov, P.-N. Lin, V. N. Mikhalenko, R. K. Campen, J. F. Bolzan, J. Cole-Dai, and B. Francou, A 25,000-year tropical climate history from Bolivian ice cores. Science 282 (1998), pp. 1858-1864.

Thompson et al., 1985 - L. G. Thompson, E. Mosley-Thompson, J. Bolzan, and B. Koci, A 1500-year record of tropical precipitation in ice cores from the Quelccaya ice cap, Peru. Science 229 (1985), pp. 971-973.

Thompson et al., 1995 - L. G. Thompson, Mosley-Thompson, M. E. Davis, P.-N. Lin, K. A. Henderson, J. Cole-Dai, J. F. Bolzan, and K.-B. Liu, Late glacial stage and Holocene tropical ice core records from Huascaran, Peru. Science 269 (1995), pp. 46-50.

Wirrmann and Mourguiart, 1995 - D. Wirrmann and Ph. Mourguiart, Late Quaternary spatio-temporal variations in the Altiplano of Bolivia and Peru. Quaternary Research 43 (1995), pp. 344-354.

Wirrmann and Oliveira Almeida, 1987 - D. Wirrmann and L. Oliveira Almeida, Low Holocene level (7700 to 3650 years ago) of Lake Titicaca (Bolivia). Palaeogeography, Palaeoclimatology, Palaeoecology 59 (1987), pp. 315-323.

Wirrmann et al., 1988 - Wirrmann, D., Mourguiart, Ph., and Oliveira, Almeida, L., Holocene sedimentology and ostracods distribution in Lake Titicaca-Paleohydrological interpretations. in Quaternary of South America and Antarctic Peninsula, Vol. 6, J. Rabassa, Ed., pp. 89-127. A. A. Balkema, Rotterdam, 1988.

Wirmann et al., 1992 - D. Wirrmann, J.-P. Ybert, and P. Mourguiart, A 20,000 years paleohydrological record from Lake Titicaca. in Lake Titicaca: A Synthesis of Limnological Analysis, C. Dejoux and A. Iltis, Eds., pp. 40-48. Kluwer Academic, Dordrecht, 1992.

Ybert, 1992 - Ybert, J.-P.1992. Ancient lake environments deduced from palynological and diatom analyses. in Lake Titicaca: A Synthesis of Limnological Analysis, C. Dejoux and A. Iltis, Eds., pp. 40-48. Kluwer Academic, Dordrecht, 1992.

Zhou and Lau, 1998 - J. Zhou and K.-M. Lau, Does a monsoon climate exist over South America?. Journal of Climate 11 (1998), pp. 1020-1040. 